\title{
Front Matter: Volume 11709
}

, "Front Matter: Volume 11709," Proc. SPIE 11709, Ultra-High-Definition Imaging Systems IV, 1170901 (16 April 2021); doi: 10.1117/12.2596681

SPIE. Event: SPIE OPTO, 2021, Online Only 


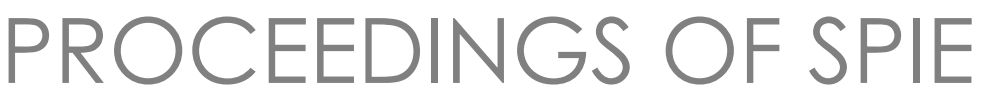

\title{
Ultra-High-Definition Imaging Systems IV
}

\author{
Seizo Miyata \\ Toyohiko Yatagai \\ Yasuhiro Koike \\ Editors
}

6-11 March 2021

Online Only, United States

Sponsored and Published by

SPIE 
The papers in this volume were part of the technical conference cited on the cover and title page. Papers were selected and subject to review by the editors and conference program committee. Some conference presentations may not be available for publication. Additional papers and presentation recordings may be available online in the SPIE Digital Library at SPIEDigitalLibrary.org.

The papers reflect the work and thoughts of the authors and are published herein as submitted. The publisher is not responsible for the validity of the information or for any outcomes resulting from reliance thereon.

Please use the following format to cite material from these proceedings:

Author(s), "Title of Paper," in Ultra-High-Definition Imaging Systems IV, edited by Seizo Miyata, Toyohiko Yatagai, Yasuhiro Koike, Proceedings of SPIE Vol. 11709 (SPIE, Bellingham, WA, 2021) Sevendigit Article CID Number.

ISSN: 0277-786X

ISSN: 1996-756X (electronic)

ISBN: 9781510642539

ISBN: 9781510642546 (electronic)

Published by

SPIE

P.O. Box 10, Bellingham, Washington 98227-0010 USA

Telephone +1 3606763290 (Pacific Time) · Fax +1 3606471445

SPIE.org

Copyright (c) 2021, Society of Photo-Optical Instrumentation Engineers.

Copying of material in this book for internal or personal use, or for the internal or personal use of specific clients, beyond the fair use provisions granted by the U.S. Copyright Law is authorized by SPIE subject to payment of copying fees. The Transactional Reporting Service base fee for this volume is $\$ 21.00$ per article (or portion thereof), which should be paid directly to the Copyright Clearance Center (CCC), 222 Rosewood Drive, Danvers, MA 01923. Payment may also be made electronically through CCC Online at copyright.com. Other copying for republication, resale, advertising or promotion, or any form of systematic or multiple reproduction of any material in this book is prohibited except with permission in writing from the publisher. The CCC fee code is $0277-$ $786 \mathrm{X} / 21 / \$ 21.00$.

Printed in the United States of America by Curran Associates, Inc., under license from SPIE.

Publication of record for individual papers is online in the SPIE Digital Library.

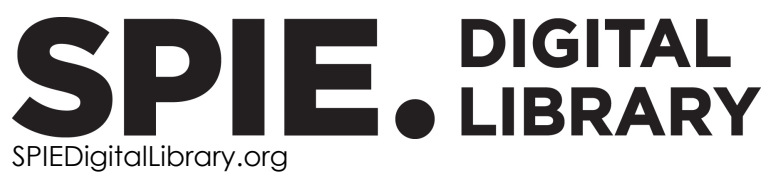

Paper Numbering: Proceedings of SPIE follow an e-First publication model. A unique citation identifier (CID) number is assigned to each article at the time of publication. Utilization of CIDs allows articles to be fully citable as soon as they are published online, and connects the same identifier to all online and print versions of the publication. SPIE uses a seven-digit CID article numbering system structured as follows:

- The first five digits correspond to the SPIE volume number.

- The last two digits indicate publication order within the volume using a Base 36 numbering system employing both numerals and letters. These two-number sets start with $00,01,02,03,04$, 05, 06, 07, 08, 09, OA, OB ... 0Z, followed by 10-1Z, 20-2Z, etc. The CID Number appears on each page of the manuscript. 


\section{Contents}

HOLOGRAPHY AND DISPLAY

1170904 Snapshot full Stokes imager by polarization cameras and its application to bio-imaging (Keynote Paper) [1 1709-1]

1170905 Speckle reduction in holographic displays (Invited Paper) [11709-2]

STORAGE

1170909 Faithful reconstruction of linear polarization holography independent of exposure energy (Invited Paper) [1 1709-6]

$11709 \mathrm{OB} \quad$ Denoising method based on deep learning used in phase retrieval in holographic data storage [11709-8]

MEDICAL HIGH-DEFINITION IMAGES

$11709 \mathrm{OD}$ Transport of intensity phase imaging with error correction using transport of phase equation (Invited Paper) [11709-10]

11709 OF Development of color correction system for medical images using color charts (Invited Paper) [11709-12]

\section{TRANSMISSION}

11709 OK High-speed data transmission via RJ45-connectored optical cable system (Invited Paper) [11709-17]

\section{UHD IMAGING SYSTEMS}

1170900 Speckle reduction in polarized laser backlight LCDs (Invited Paper) [11709-21]

11709 OP Influence of pre-polymerization process on optical properties of phenanthrenequinone-doped polymethyl methacrylate photopolymer (Invited Paper) [11709-22] 


\section{POSTER SESSION}

11709 OU Wavelength coded volume holographic gratings based dual wavelength fluorescence imaging system [11709-27]

Proc. of SPIE Vol. 11709 1170901-4

Downloaded From: https://www.spiedigitallibrary.org/conference-proceedings-of-spie on 26 Apr 2023 Terms of Use: https://www.spiedigitallibrary.org/terms-of-use 